\section{Enhancement of underused cervical cancer prevention services in rural Oaxaca, Mexico}

\author{
Martha Givaudan, ${ }^{1}$ I win Leenen, ${ }^{2}$ \\ Susan Pick, ${ }^{1,3}$ Andrea Angulo, ${ }^{1}$ \\ and Ype H. Poortinga ${ }^{4,5}$
}

Suggested citation: Givaudan M, Leenen I, Pick S, Angulo A, Poortinga YH. Enhancement of underused cervical cancer prevention services in rural Oaxaca, Mexico. Rev Panam Salud Publica. 2008;23(2):135-43.

Key words: cervix neoplasms prevention, rural population, women's health, health policy, Mexico.

\footnotetext{
1 Instituto Mexicano de Investigación de Familia y Población, A.C., Málaga Norte No. 25, Colonia Insurgentes Mixcoac, México, D.F., CP 03920, Mexico. Send correspondence and reprint requests to: Martha Givaudan, Malaga Norte 25, Colonia Insurgentes Mixcoac, Mexico City, Mexico; telephone 52555 6115876, ext. 252; e-mail: marthag@ imifap.org.mx.

2 Universidad Complutense de Madrid, Madrid, Spain.

3 Universidad Nacional Autónoma de México, México, D.F., Mexico.

4 University of Tilburg, Tilburg, Netherlands.

5 University of Leuven, Leuven, Belgium.
}

"Whether it is the two hour walk to the nearest clinic, local myths or poor health services millions of women worldwide never undergo cervical cancer screening and hundreds of thousands die prematurely without ever knowing why they were ill." (Alliance for Cervical Cancer Prevention, 2004)

Cervical cancer is a global public health issue. According to a recent report by the Alliance for Cervical Cancer Prevention (1) an estimated 274000 women fall victim to cervical cancer each year, $80 \%$ of whom live in low-income countries. The problem has been associated with women's inadequate knowledge of the disease and its prevention (2-4) and the low expertise of health professionals (5) as well as their lack of cultural sensitivity $(6,7)$. In industrialized countries, the incidence of and death rate from cervical cancer have significantly decreased over the past 50 years as a result of widespread implementation and use of Papanicolaou or Pap smear testing $(8,9)$. The Pap smear test is an effective screening tool for cervical neoplasia, a precursor of cervical cancer, which is mostly caused by human papilloma virus. Treatment of cervical cancer precursors is usually highly successful.

In Mexico, as in most developing countries, rates of cervical cancer reflect prevalent high-risk behavior, myths about prevention, and underuse of medical services. Cervical cancer is the leading cause of death among women around 35 years of age (10) and the second leading cause of death among adult women aged 15-64 years (11). The mortality rate from cervical cancer is estimated at 10.2 per 100000 women (12). Every day in Mexico, 12 women die from cervical cancer; the annual growth in cervical cancer deaths being $0.76 \%$. Women in rural areas have a 3.07 times higher risk of dying from this illness than women in urban centers (13).

Although the Mexican Health Ministry has provided free or very low cost cancer-screening services throughout the country and prioritized the need for cervical cancer programming (12), these services remain notoriously underutilized, most notably in low-income, low-education, rural communities $(14,15)$. Some efforts are known to have failed because they focused on younger women and did not include the older at-risk group (16). Social norms and a strong distrust in allopathic medicine contribute to alienating women from institutional health care (17). Even though the costs of screening are favorable, the sociocultural context has not been 
conducive to widespread use of screening and diagnostic tests.

In a study of women in Mexico City and rural regions of the Mexican state of Oaxaca, the main predictors of use of the Pap smear were knowledge of what the Pap test is meant for, socioeconomic and educational level, and access to social security (18). As recently as a decade ago, an evaluation of Mexico's national cervical cancer detection program found that only $40 \%$ of women living in rural areas knew the purpose of the Pap smear. Most women who used diagnostic programs did so only when they showed symptoms. Moreover, screening was found to be less common among older, less educated, less parous women; nonusers of oral contraceptives; and women without a history of venereal diseases $(18,19)$.

In this article, we discuss a health education program, named Porque me quiero, me cuido (Because I like myself, I take care of myself) (20), that was implemented in rural and indigenous populations in Valles Centrales in Oaxaca, one of Mexico's poorest and most rural states. The Valles Centrales region occupies a third of the state's territory. In Oaxaca, the mortality rate due to cervical cancer is 12.4 per 100000 women (21). Hence, the goal of the program was to promote the use of screening services. The program is geared toward increasing knowledge and skills, enabling women to take preventive measures against cervical cancer, and promoting Pap smear tests. A first version of the program was implemented with support from the local health authorities in the state of Oaxaca (17).

The first question to be answered in this article is whether the Porque me quiero, me cuido program had a demonstrable impact on health behavior, especially in the form of women seeking more Pap smear tests. A further question was to examine whether there was a demonstrable increase in knowledge, attitudes, and behaviors related to cervical cancer and prevention as a consequence of the program.

\section{THE PROGRAM}

Porque me quiero, me cuido was developed at the Instituto Mexicano de Investigación de Familia y Población (IMIFAP), a Mexican nongovernmental organization with a focus on health education and community development of groups in Latin America with limited education. Since its development, the program has been incorporated as part of an integral sustainable human development program called Yo quiero, yo puedo (I want to, I can) and the cancer module is known as Yo quiero, yo puedo... prevenir el cancer (I want to, I can ... prevent can- cer). The conceptualization and implementation strategy adopted in the program, incorporating core issues discussed in the literature, have been presented elsewhere $(17,22-24)$. The guiding principles can be summarized as follows.

First, a program must be rooted in the needs of the target population $(4,7)$. Second, changes in behavior have to be initiated at the level of specific situations (25) by helping program clients develop or acquire "tools" in the form of knowledge and communication skills enabling them to change their behaviors. A third requirement in building health education programs is that the context, such as socioeconomic variables, in which the target population lives should be taken into account $(7,26)$. Fourth, program advocacy and dissemination of results are an inherent part of health promotion. The fifth and last principle underlying the IMIFAP approach is an emphasis on evaluation at all stages of the program $(25,27)$; there has to be accountability to all important stakeholders.

Workshop sessions and educational and promotional materials (training manual, flipchart, and a video) for the program Porque me quiero, me cuido were designed on the basis of background research exploring the needs of the target population. The workshops are conducted by local women, called health promoters, who took part in a 1-week training program in which they were program participants and in addition were given instructions on how to conduct workshops. Workshop sessions are highly interactive and include discussions and role playing as well as the presentation of factual information. Thus, the workshops foster the development of knowledge and skills that empower women to make decisions about their own sexual and reproductive health. They provide information to enhance women's knowledge of their bodies, physical rights, and risks; information on how to take care of their health; and information on skills to make choices for preventing cervical cancer and how to realize these skills in an assertive manner. The workshops are composed of eight 2-hour weekly sessions with groups of 15-25 women.

There was also a workshop for men consisting of three 2-hour sessions: two for men only and one for men and their partners. The workshop focused on sexual and reproductive health, including the Pap test and skills such as communication and interaction with one's partner. Another module, directed at professional health care providers (doctors and nurses), consisted of two 4-hour sessions during which participants had the opportunity to exchange experiences and to reflect on their role and the way they interacted with women. Finally, a dissemination promotion campaign was conducted in communities as part of program advocacy. For 
further information on these additional activities, refer to Givaudan et al. (17).

\section{Method}

Participants. Ten communities in Valles Centrales, Oaxaca, with low annual rates of screening for cervical cancer were selected on the basis of information provided by the Ministry of Health. ${ }^{6}$ Women taking part in the program ranged from 15 to 64 years old. For the purpose of evaluation, six similar communities were selected in the same region from which participants were drawn to form the control group in a questionnaire study. The sampling technique amounted to selection with replacement; women participating in the premeasurement might take part also in the postmeasurement, but there was no attempt at matching. In accordance with common practice in Latin America, neither the women nor their communities were compensated for their cooperation. However, they were often interested in being interviewed because of the opportunity to converse with someone about health matters.

In each community (village) where the program was administered, one to four rural health promoters were recruited to implement the program. They were local women who had to be able to read and write. The selection procedure included the recommendation of a local health care provider (doctor or nurse) and an interview with each candidate. Many women in both the control and the experimental communities also took part in a program called Oportunidades (Opportunities), formerly called Progresa (Progress), a federally funded program that provides financial and economic support for nutrition, education, and health to the poorest communities of Mexico. A condition for receiving benefits is to attend talks about health that are given periodically in the villages. The objectives overlap with the program described here. The two main differences are that the Oportunidades program provides information on a wide range of health issues and is carried out through public lectures to large groups, whereas Porque me quiero, me cuido focuses on cervical cancer and uses participatory techniques with small groups.

\footnotetext{
6 The State Department of Health assisted in obtaining demographic data for each of the villages. We needed to know the number of women between 15 and 50 years of age to assess the reach of the program. Although municipalities are supposed to provide information to the department about the composition of the population, this information was not available for all villages. We estimated the number of women in the stipulated age range in the case of two experimental villages on the basis of the total size of the population and the total number of women in the other eight villages, assuming that age and gender distributions were the same in all villages. The two estimates were close in value and the average was taken.
}

In each village, local health promoters invited women to attend the workshops by using door-todoor visits, by messages through loudspeakers, by support of local authorities and health providers, and by getting in touch with groups such as neighbors and families. A total of 2177 women attended the workshops. More than half of them attended all eight sessions, less than $10 \%$ attended three or fewer times.

Evaluation procedures. The impact of the program was quantified by (1) comparing the numbers of Pap smear tests as recorded in local health clinics before and after program implementation, and (2) a questionnaire that aimed at assessing knowledge, opinions, attitudes, and behavior of women regarding cervical cancer.

\section{Numbers of Pap smears}

Records of local clinics were examined to retrieve the numbers of Pap smears conducted in the various villages for the year the program was implemented and for the preceding year. It was impossible to obtain a full set of data because in some clinics the records of the previous year could not be found. We retrieved records for both years in four control and eight experimental villages.

Participants in the questionnaire study. The instrument was applied in a pretest-posttest design with an experimental and a control group. At least 20 women of reproductive age were interviewed in each of the 10 experimental and 6 control villages before the program started and 10 months after its completion. Each round of data collection was completed within 2 months.

Each interviewer was told to start with a certain house. If a woman in the appropriate age range was present, she was asked for an interview. If an interview was conducted, the interviewer would skip a few houses (the number depended on the size of the village) and go to another house. If no interview was administered (in the case of no cooperation or no woman present in the right age range), the interviewer would go to the next house. The procedure was the same for control and experimental villages, implying that in the latter villages women were included who had not attended the program.

Questionnaire. The questionnaire was based on an instrument used previously to assess a preliminary version of the program (17). It begins with five questions asking for sociodemographic data (age, educational level, participation in the Oportunidades 
program, civil status). The remainder of the questionnaire comprises seven scales:

(1) Knowledge about health, hygiene, and sexuality (20 items, such as, Do you think only women who have sexual intercourse can get cervical cancer? Do you think too much dust can cause cervical cancer?).

(2) Attitudes (12 items, such as, Would you be concerned if other persons from your community knew you had a Pap smear test? If cancer was detected from the test, would you prefer to not know?).

(3) Intentions (16 items, such as, Would you have a Pap smear test performed by a male doctor? Have you already thought about when you will go for your next Pap smear?).

(4) Health-oriented behaviors (12 items, such as, In the last month have you checked your sexual organs? Have you ever had a Pap smear?).

(5) Partner's attitude (5 items, such as, Would it bother your partner that you have had a Pap smear?).

(6) Partner's behavior (5 items, such as, In the last year, did your partner and you go together to the health center to see a doctor?).

(7) Social desirability (10 items, such as, Does it make any difference to you whether it is a male or female doctor who performs your Pap smear? Do you wash your hands every time before and after you go to the toilet?).

Responses for most items were limited to three options: agreement, disagreement, and an option expressing uncertainty or unwillingness to answer. A few items were open questions where a short response was expected (for example, naming some symptoms). The questionnaire took up to an hour to complete.

Questionnaire administration. The data were collected by five interviewers (social science students from a university in Oaxaca City), who were trained in a 5-hour session where they practiced by role playing among themselves. They worked in each community in pairs. In view of the low educational level of most women, the instrument was applied as a structured interview.

The total number of instruments was 679 (200 pretest experimental, 120 pretest control, 239 posttest experimental, 120 posttest control).

\section{Analysis of questionnaire scores}

For each respondent, scores on items in the seven scales were obtained by assigning a 1 if the response indicated agreement with the objectives of the program and 0 in the case of disagreement or uncertainty/unwillingness to answer. About 3\% of missing values (due to items without a response) were omitted from the analyses. To the obtained item scores of each scale, except the two behavior scales, we applied the one-parameter logistic model (OPLM) (28), which is a model from Item Response Theory similar to Birnbaum's (29) two-parameter logistic model. This procedure yielded a score for each respondent on each scale. To fix the origin and unit of the scale, the score distributions were standardized (with a mean of 0.00 and a standard deviation of 1.00).

As a next step, the scale scores were entered as dependent variables in a multilevel (or hierarchical) model $(30,31)$ with participation in the workshop and demographic information as independent variables. We opted for a multilevel analysis because the women were nested in communities and women from the same community were expected to be more homogeneous in their responses than women from different communities.

Because the behavioral items (questions about the behavior of women and their partners) addressed quite specific and heterogeneous situations (which implies a violation of the unidimensionality assumption in OPLM), we did not try to construct a scale for these items. Instead, as in previous cases (32), we analyzed them separately using a logistic multilevel model with the dichotomous item score as the dependent variable and participation in the workshop and demographic information as independent variables.

\section{RESULTS}

For 8 of the 10 experimental communities, we obtained records of Pap smears over 2 years. In the year before the program was implemented, 1074 Pap smears were taken. During the year of implementation, there were 1306 Pap smears, while the total number of women in these villages within the program's age range was calculated to be 4865 . Under the assumption that there was no change in the size of the population, this corresponds to an increase of $22 \%$ to $27 \%$. A multilevel analysis (with women nested in villages) shows that the probability of women having a Pap smear significantly increased in the experimental villages compared with the control villages, $t(11)=2.66, p=0.02$.

Table 1 presents descriptive statistics on the sociodemographic characteristics of the women who were administered the questionnaire, separating control and experimental villages and pretest and posttest questionnaires. Statistically significant 
TABLE 1. Descriptive statistics for control and experimental groups in both applications, Oaxaca, Mexico, 2001-2002

\begin{tabular}{|c|c|c|c|c|c|c|c|}
\hline \multirow[b]{2}{*}{ Moment } & \multirow[b]{2}{*}{ Treatment } & \multirow[b]{2}{*}{$n$} & \multicolumn{2}{|c|}{ Age (years) } & \multirow{2}{*}{$\begin{array}{c}\text { Schooling } \\
(\%)\end{array}$} & \multirow{2}{*}{$\begin{array}{l}\text { Has partnerb } \\
(\%)\end{array}$} & \multirow{2}{*}{$\begin{array}{c}\text { Oportunidades } \\
(\%)\end{array}$} \\
\hline & & & Mean & $S D^{d}$ & & & \\
\hline \multirow[t]{2}{*}{ Pre } & Control & 120 & 37 & 14 & 37 & 68 & 11 \\
\hline & Experimental & 200 & 40 & 15 & 41 & 70 & 32 \\
\hline \multirow[t]{2}{*}{ Post } & Control & 120 & 37 & 17 & 54 & 52 & 18 \\
\hline & Experimental & 239 & 39 & 12 & 34 & 75 & 56 \\
\hline
\end{tabular}

a Percentage of women who initiated secondary school.

b Percentage of women with a (sexual) partner.

c Percentage of women belonging to the Oportunidades program.

d Standard deviation.

differences among the four groups occur for all variables except age. With respect to education level and civil state, the women in the posttest control group differ from those in the other groups, with the former group including more women who initiated secondary school and who did not have a partner. Furthermore, Table 1 shows that in the experimental groups more women participated in the state's Oportunidades program. This program had already been running for a few years and is unlikely to account for the increase in Pap smears in the experimental villages. In the multilevel analyses presented next, the differences among these groups are accounted for by including the sociodemographic variables as covariates.

The main results of the questionnaire are presented in Table 2. The rows of the table refer to dependent variables and the columns refer to independent variables (or effects). There are three sets of dependent variables: (1) continuous scores based on five subscales in the questionnaire, (2) binary scores based on self-reported health behavior items, and (3) binary scores on items for which the women report the behavior of their partners.

The first column in the body of Table 2 gives the value of the intercept. Because of the way the independent variables were defined, the intercept value corresponds to the expected score on the pretest of a woman of mean age, with limited schooling, without a partner, who does not take part in the Oportunidades program, and who has a mean score for social desirability. The other columns on the left side of Table 2 are control variables: "Age" refers to the difference in the dependent variable associated with a difference of 1 year of age. This implies, for example, that a woman 30 years old has an expected score on knowledge 0.005 standard deviation unit above the expected score of a 29-year-old, the values for all other variables being equal. "Schooling" was treated as a dichotomous variable with secondary school attendance or higher as one category, and education at the pri- mary school level or no school attendance as the other category. The table shows that the expected score for knowledge among more educated women was 0.04 standard deviation higher than for the less educated. "Has partner" is a dichotomous variable with a positive score when an interviewee reported having a partner. "Oportunidades" refers to participation (versus nonparticipation) in the Oportunidades program. The inclusion of "Social desirability" (which represents the score on the social desirability scale obtained from the OPLM analyses) as an independent variable statistically corrects the women's responses on the attitude, intention, and behavior items for giving the socially desirable answer. Theoretically, social desirability cannot affect knowledge; therefore, this variable was not included as a control variable for knowledge (the knowledge scale contained items with negative responses and items with positive responses).

On the right side of Table 2 are three variables referring to program-related effects. The first and second are binary variables. The first refers to the moment of testing (pre and post) and the second refers to treatment status (experimental versus control communities). The third variable refers to the number of sessions the interviewee attended (based on the attendance lists) and indicates the effect on the dependent variable of a unit change in workshop attendance (of eight workshops). For example, the increase in knowledge for a woman from an experimental village who attended all sessions can be estimated at 0.49 standard deviation (moment effect + treatment effect: $-0.17+0.66=0.49)$. For each session a woman missed, her knowledge can be estimated to decrease by 0.056 standard deviation. For example, for a woman who attended four sessions instead of all eight, the effect of the program can be expected to have been lower by $4 \times 0.056=0.224$ standard deviation.

Of the continuous variables, "knowledge" shows a highly significant and substantial treatment effect, which can be largely accounted for by 
TABLE 2. Parameter estimates with knowledge, attitude, and reported actual behaviors as dependent variables, Oaxaca, Mexico, 2001-2002

\begin{tabular}{|c|c|c|c|c|c|c|c|c|c|}
\hline \multirow[b]{2}{*}{ Dependent variable } & \multicolumn{6}{|c|}{ Control variable effects } & \multicolumn{3}{|c|}{ Intervention-related effects } \\
\hline & Intercept & Age & Schooling & $\begin{array}{l}\text { Has } \\
\text { partner }\end{array}$ & $\begin{array}{l}\text { Oportu- } \\
\text { nidades }\end{array}$ & $\begin{array}{c}\text { Social } \\
\text { desirability }\end{array}$ & $\begin{array}{c}\text { Moment } \\
\text { (pre/post) }\end{array}$ & $\begin{array}{l}\text { Treatment } \\
\text { (exp/cont) }\end{array}$ & Sessions \\
\hline \multicolumn{10}{|l|}{ Continuous variables } \\
\hline Knowledge & $-0.20^{a}$ & 0.005 & 0.04 & 0.07 & $0.35^{\mathrm{b}}$ & & -0.17 & $0.66^{b}$ & $0.056^{a}$ \\
\hline Attitude & $-0.38^{b}$ & $-0.017^{b}$ & $0.43^{b}$ & $0.19^{c}$ & -0.07 & $0.09^{c}$ & 0.18 & -0.07 & -0.017 \\
\hline Intention & $-0.44^{b}$ & $-0.010^{b}$ & $0.26^{\mathrm{b}}$ & $0.23^{b}$ & 0.13 & $0.33^{b}$ & $0.26^{c}$ & 0.10 & 0.017 \\
\hline Partner attitude & $-0.21^{c}$ & -0.004 & $0.51^{b}$ & & -0.01 & $0.14^{b}$ & -0.11 & 0.06 & -0.013 \\
\hline \multicolumn{10}{|l|}{ Binary variables } \\
\hline Asking doctors questions & $2.20^{\mathrm{b}}$ & -0.001 & 0.52 & 0.51 & 0.16 & $0.42^{\mathrm{c}}$ & 0.80 & -0.26 & 0.040 \\
\hline Vaginal rinse & $1.49^{b}$ & 0.010 & $0.56^{c}$ & -0.05 & -0.00 & $-0.20^{a}$ & -0.18 & 0.66 & -0.034 \\
\hline Eat fruit & $1.34^{\mathrm{b}}$ & 0.008 & 0.23 & $0.54^{c}$ & $0.56^{\mathrm{a}}$ & 0.18 & 0.15 & -0.63 & -0.028 \\
\hline Inspecting sexual organs & $-1.47^{b}$ & 0.001 & $0.79^{b}$ & $0.35^{\mathrm{a}}$ & 0.08 & $0.49^{b}$ & 0.16 & 0.55 & 0.082 \\
\hline Explain Papanicolaou & $-0.71^{b}$ & 0.006 & 0.11 & 0.26 & $0.40^{\mathrm{a}}$ & $0.52^{b}$ & $0.54^{\mathrm{a}}$ & $1.35^{\mathrm{c}}$ & $0.150^{\mathrm{a}}$ \\
\hline Recent Papanicolaou & $-1.28^{b}$ & $0.020^{b}$ & 0.21 & $0.51^{c}$ & $0.44^{\mathrm{a}}$ & $0.52^{b}$ & 0.39 & 0.52 & $0.183^{c}$ \\
\hline Condom use & $-1.40^{\mathrm{b}}$ & $-0.071^{b}$ & 0.35 & & 0.10 & $0.28^{\mathrm{c}}$ & 0.30 & $-0.47^{a}$ & 0.024 \\
\hline Doctor visit sex. symptoms & $1.85^{b}$ & $0.019^{c}$ & -0.23 & $-0.45^{\mathrm{c}}$ & $0.48^{\mathrm{a}}$ & $0.24^{\mathrm{C}}$ & -0.03 & -0.74 & 0.004 \\
\hline Talk to partner contraception & $0.42^{\mathrm{c}}$ & $-0.054^{b}$ & $1.09^{b}$ & & -0.25 & $0.27^{\mathrm{c}}$ & -0.10 & -0.25 & -0.015 \\
\hline Visit doctor in secret & $1.90^{\mathrm{b}}$ & $-0.029^{c}$ & $0.80^{c}$ & & -0.16 & $-0.29^{a}$ & 0.05 & -1.16 & $-0.221^{\mathrm{a}}$ \\
\hline Assertivity to partner & 0.27 & 0.004 & $1.07^{b}$ & & -0.13 & $0.23^{c}$ & 0.10 & 0.55 & 0.089 \\
\hline Refusing sex to partner & $1.19^{b}$ & -0.015 & 0.07 & & $-0.47^{a}$ & $0.27^{c}$ & 0.03 & 0.42 & 0.044 \\
\hline \multicolumn{10}{|l|}{ Partner } \\
\hline Proposes condom & $-1.50^{b}$ & $-0.073^{b}$ & -0.37 & & -0.17 & 0.13 & 0.05 & 0.27 & 0.062 \\
\hline Joins to doctor & 0.12 & -0.012 & 0.00 & & 0.32 & -0.05 & 0.53 & -0.39 & 0.037 \\
\hline Prepares food & 0.19 & -0.011 & 0.40 & & 0.10 & $0.19^{\mathrm{a}}$ & 0.25 & 0.84 & 0.086 \\
\hline Is interested & $1.53^{b}$ & -0.016 & 0.39 & & -0.23 & $0.26^{\mathrm{a}}$ & 0.37 & 0.60 & 0.029 \\
\hline Gets upset (contraception) & $2.36^{\mathrm{b}}$ & $-0.031^{a}$ & 0.75 & & -0.00 & $0.38^{\mathrm{a}}$ & 0.60 & 2.36 & 0.354 \\
\hline
\end{tabular}

a Estimated parameter value is significantly different from $0(p<0.10)$.

b Estimated parameter value is significantly different from $0(p<0.01)$.

${ }^{c}$ Estimated parameter value is significantly different from $0(p<0.05)$.

attendance at the workshops. In contrast, the effects of treatment on the subscales for attitude, perceived attitude of partner, and intention were small. The low estimates for session effects are in line with these findings.

For reasons explained previously, the items on reported behaviors were entered as dependent variables in separate (logistic multilevel) analyses. As a consequence, the estimates are less stable and tend to have a larger margin of error than scores based on scales consisting of several items. Table 2 shows the results of the 12 self-reported behaviors and 5 reported behaviors of the partner. A statistically significant result $(p<0.05)$ for the treatment effect was obtained for only one item: women who attended the workshops talk more frequently about the importance of the Pap test (this was an open item). As far as reported behavior of partners is concerned, the treatment effects varied over items, although four of five were positive.

Table 2 further presents estimates for the control variables. Older women are more likely to have had a Pap smear test, and younger women are more likely to report condom use. Generally, education turned out to be an important variable, with significant effects on attitudes, inspection of sexual organs, hygiene, and asserting oneself vis-à-vis one's partner. In contrast to formal education, the effects of having a partner were difficult to interpret. Participation in the Oportunidades program had a positive effect on knowledge and on Pap smear testing, both in its explanation and in reporting a recent test.

We would like to draw attention to the considerable effect of social desirability on almost all dependent variables. This suggests that social desirability is an important variable that must be considered when relying on self-reports in evaluations of program success. The multilevel analyses further imply the estimation of (random) effects that model differences among the villages (beyond differences already explained by the treatment variable). These estimates are not reported here because no significant effects were found for any of the items and because the results are of less substantive interest. 


\section{DISCUSSION AND CONCLUSIONS}

The main finding of this study is clear. There was a significant increase in the number of rural and indigenous women who came to have a Pap smear in the communities where the program was implemented compared with the control villages, where there was no evidence of an increase. Further support for the success of the program comes from the questionnaire study, which also provides insight into how best to explain the success of the program. The results in Table 2 show that participation in the workshops contributed to an increase in knowledge about cervical cancer and its prevention. Effects on behavior tended to be smaller, and effects on underlying variables, such as intentions and attitudes, were rather minimal. This pattern fits in with the idea, mentioned in the introduction, that knowledge and skills to deal with specific situations change before there are changes in psychological variables that reflect more general characteristics of a person, as is the case with personal attitudes $(21,23)$ as well as the fact that often in communities where there is little control over one's actions, the concept of intention is not relevant (33).

Another finding reflected in Table 2 is the importance of social desirability when the effect of intervention is assessed through self-reports. Social desirability is a tendency to give an answer in agreement with prevailing norms and social expectations. The tendency to comply with such expectations is higher among close-knit communities where following social norms is more closely controlled (34). This response style can strongly affect self-reports (35). However, such effects are rarely accounted for in quantitative or qualitative program evaluations $(36,37)$. The estimated effect size for this subscale sometimes exceeds the estimates for treatment effects (see, for example, the attitude and intention subscales). This means not that the treatment had no effect but that the effects of the treatment would have been seriously misrepresented if this response style effect had not been accounted for.

Attending the Oportunidades program is mostly associated with positive outcomes and the present program can probably be said to build on the more general Oportunidades lectures. The focus of this program on cervical cancer and its prevention leads to higher estimates for (specific) knowledge increase and Pap-smear-related behaviors.

Apart from the relevance for the target women of the program content, effectiveness, in our view, has to be attributed to two factors: the didactic mode and the attention to context. The workshops were designed to be highly interactive.
Women were encouraged to talk to each other and to ask questions. During the supervised sessions, it was noted that this did happen and there was active participation in simulations and other group activities. In addition, there was a central role for local health promoters who know the circumstances of the women in their workshops. During their week-long training, the health promoters went through the program, and they also learned how to conduct workshop sessions.

The second factor, attention to context, is reflected in an array of activities, including workshops for men and health professionals, dissemination activities in the form of public announcements and displays, and advocacy activities aimed at community officials (17). It was difficult for any villager to not know about the program. Testimonials of the women indicated that such public visibility questioned restrictive social norms and opened up opportunities for change. The success of interventions paying attention to context has also been reported in other countries such as Ghana (38), Peru (39), and Greece (40).

Although we have assessed the results of the program as positive, we realize that the design and execution of the questionnaire study was not optimal. The study would have been stronger if the same women had participated in the pre- and posttest study, but with bringing in a team of qualified interviewers from outside the communities we did not have that choice. In the villages, it is impossible to make prior arrangements for an interview. One has to work with whoever is available at a given time. Also, the number of villages was fairly small, allowing for a larger margin of error than would have been the case with higher numbers. This lack of precision was compounded by the absence of demographic data for some of the villages needed to estimate the percentage increase in Pap smears. Finally, some of the estimates in Table 2 have a substantial margin of error because of the unreliability of single-item variables. Complex field studies cannot reach the level of precision and control of laboratory experiments, but they can help to provide insights not otherwise available.

The findings we reported mainly concern the effectiveness of the program, but they also have some relevance for an evaluation of efficiency. The question of efficiency is important for decisions about future scaling up of the program to reach much larger numbers of women. To estimate the economic benefits, we would need to make assumptions about the maintenance and further spread of individual health care practices in communities as a consequence of the program, for which we lack a sufficient foundation. However, 
we would like to emphasize that the involvement of local health promoters as workshop facilitators is a cost-efficient way to implement a highly interactive program at relatively low cost.

In summary, the findings show that the Porque me quiero, me cuido program has led to a significant increase in the number of Pap smears among indigenous and rural populations in the region of Oaxaca, Mexico, where it was implemented and in knowledge relevant for preventing cervical cancer. Several features of the program can help explain these results, of which the two most important are the extension of program activities to include the social environment and the highly participatory method of implementation through a closely accompanied cascade system in which welltrained and closely supervised local women play a key role.

Acknowledgments. This project was made possible by a grant from the Commission of European Communities, MEX/B7-6310/IB/99/0251. We acknowledge the support of Carmen Fuertes and Tere Venguer in the fieldwork and program development. Completion of this article was facilitated by a research fellowship at the Harvard Center for Population and Development Studies, Cambridge, Massachusetts, awarded to Susan Pick. None of the authors had any conflicts of interest in producing this work.

\section{SINOPSIS}

\section{Incremento en el uso de los servicios de prevención de cáncer cervicouterino en zonas rurales de Oaxaca, México}

En este trabajo se analizan los resultados de la aplicación del programa educacional Porque me quiero, me cuido, denominado actualmente Yo quiero, yo puedo. . . prevenir el cáncer, en poblaciones rurales e indígenas de Valles Centrales, estado de Oaxaca, una de las regiones más pobres de México. Este programa está dirigido a promover el uso de servicios de tamizaje y la prevención del cáncer cervicouterino mediante el cambio de conducta de las personas y la comunidad. Para ello se realizaron talleres interactivos enfocados al desarrollo de habilidades y conocimientos en las mujeres de 15 a 64 años de edad. Estos talleres se complementaron con campañas en la comunidad y talleres para hombres con el fin de conseguir su apoyo. Se cuantificaron las pruebas de Papanicolau realizadas en las 10 poblaciones intervenidas y en 6 poblaciones con características similares empleadas como control. Además se evaluó mediante un cuestionario los cambios en la conducta, los conocimientos y las actitudes. Se observó un numero significativamente mayor de pruebas de Papanicolau realizadas en las poblaciones intervenidas con respecto a las de control $(\mathrm{P}=0,02)$. Se comprobaron cambios positivos en el nivel de conocimientos de las mujeres respecto a las causas del cáncer cervical y las medidas para prevenirlo.

Palabras clave: prevención de cáncer de cuello uterino, población rural, salud de la mujer, política de salud, México.

\section{REFERENCES}

1. Alliance for Cervical Cancer Prevention. Women's stories, women's lives: experiences with cervical screening and treatment. Available from: http://www. phishare.org/documents/ACCP/2598/. Accessed 7 December 2005.

2. Adanu RM. Cervical cancer knowledge and screening in Accra, Ghana. J Womens Health Gend Based Med. 2002; 11(6):487-8.

3. Ajayi IO, Adewole IF. Knowledge and attitudes of general outpatient attendants in Nigeria to cervical cancer. Cent Afr J Med. 1998;44(2):41-3.

4. Masood S. A plea for worldwide volunteer cervical cancer education and awareness program. A proposal from the International Academy of Cytology Committee on Cancer Detection for Medically Underserved Women. Acta Cytol. 1999;43(4):539-43.

5. Fylan F. Screening for cervical cancer: a review of women's attitudes, knowl- edge, and behavior. Br J Gen Pract. 1998; 48(433):1509-14.

6. Holroyd E, Twinn S, Adab P. Sociocultural influences on Chinese women's attendance for cervical screening. J Adv Nurs. 2004;46(1):42-5.

7. Bingham A, Bishop A, Coffey P, Winkler J, Bradley J, Dzuba I, et al. Factors affecting utilization of cervical cancer prevention services in low-resource settings. Salud Pública Méx. 2003;45(Suppl 3): S408-16.

8. Franco EL, Duarte-Franco E, Ferenczy A. Prospects for controlling cervical cancer at the turn of the century. Salud Pública Méx. 2003;45(Suppl 3):S367-75.

9. Pisani P, Parkin DM, Bray F, Ferlay J. Erratum: estimates of the worldwide mortality from 25 cancers in 1990. Int J Cancer. 1999;83:18-29.

10. Jimenez-Perez M, Thomas DB. Has the use of Pap smears reduced the risk of invasive cervical cancer in Guadalajara, Mexico? Int J Cancer. 1999;82(6):804-9.
11. Rangel JI, Pérez Rendón M, Rivera L, Velasco H, Hernández Girón C. Prevalence of dysplasias and cervical cancer in women in the State of Querétaro (Mexico). Clinical and Translational Oncology. 2003;5(8):471-475.

12. Secretaria de Salud. Statistics of mortality related to reproductive health: Mexico, 1997 (indicators). Salud Pública Méx. 1999:41:138-46.

13. Palacio-Mejía LS, Rangel-Gómez G, Hernández-Ávila M, Lazcano-Ponce M. Cervical cancer, a disease of poverty: mortality differences between urban and rural areas in Mexico. Salud Pública Méx. 2003;45(3):315-25.

14. Coughlin SS, Uhler RJ, Richards T, Wilson KM. Breast and cervical cancer screening practices among Hispanic and non-Hispanic women residing near the United States-Mexico border, 1999-2000. Fam Community Health. 2003;26(2): 130-9. 
15. Escandon-Romero C, Benitez-Martinez MG, Navarrete-Espinoza J, VazquezMartinez JL, Martinez-Montanez OG, Escobedo-de la Pena J. Epidemiology of cervical cancer at the Mexican institute of social security. Salud Pública Méx. 1992;34(6):607-14

16. Lazcano-Ponce EC, Moss S, CruzValdez A, Alonso de Ruiz P, CasaresQueralt S, Martinez-Leon CJ, et al. The factors that determine participation in cervical cancer screening in the state of Morelos. Salud Pública Méx. 1999;41(4): 278-85.

17. Givaudan $\mathrm{M}$, Pick $\mathrm{S}$, Poortinga $\mathrm{YH}_{\text {, }}$ Fuertes C, Gold L. A cervical cancer prevention program in rural Mexico: addressing women and their context. J Commun Appl Soc Psychol. 2005;15: 338-52.

18. Lazcano-Ponce EC, Najera-Aguilara P, Buiatti E, Alonso de Ruiz P, Kuri P, Cantoral $\mathrm{L}$, et al. The cervical cancer screening program in Mexico: problems with access and coverage. Cancer Causes Control. 1997;8(5):698-704.

19. Herrero R, Brinton LA, Reeves WC, Brenes MM, de Britton RC, Gaintan E, et al. Screening for cervical cancer in Latin America: a case-control study. Int J Epidemiol. 1992;21(6):1050-6.

20. Fuertes, C. y Venguer, T. Porque me quiero, me cuido: un taller integral para la prevención y detección temprana del cáncer cérvico uterino. (Rotafolio). México: Unión Europea, IMIFAP-Educación, salud y vida; 2001.

21. Deininger K, Minten B. Poverty, policies, and deforestation: the case of Mexico, research project on social and environmental consequences of growthoriented policies. Working Paper, Policy Research Department. Geneva: World Bank; 1996

22. Pick S, Givaudan M, Poortinga YH. Sexuality and life skills education: a multi- strategy intervention in Mexico. Am Psychol. 2003;58(3):230-4.

23. Pick S, Poortinga Y. Marco conceptual y estrategia para el diseño e instrumentación de programas para el desarrollo: una visión científica, política y psicosocial. Rev Latinoam Psicol. 2005;37(3): 445-6.

24. Pick S, Poortinga $\mathrm{YH}$, Givaudan M. Integrating intervention theory and strategy in culture-sensitive health promotion programs. Prof Psychol Res Pr. 2003; 34(4):422-9.

25. Friedell G, Linville L, Rubio A, Wagner $\mathrm{W}$, Tucker $\mathrm{T}$. What providers should know about community cancer control. Cancer Pract. 1997;5(6):367-74.

26. Shanta V, Krishnamurthi S, Gajalakshmi C, Swaminathan R, Ravichandran K. Epidemiology of cancer of cervix: global and national perspective. J Indian Med Assoc. 2000;98:49-52.

27. Rossi PH, Freeman HE. Evaluation: a systematic approach, 5th ed. Newbury Park, CA: Sage Publications; 1993.

28. Verhelst ND, Glas CAW. The one parameter logistic model. In: Fisher GH, Molenaar IW, eds. Rasch models: foundations, recent developments, and applications. New York: Springer; 1995. Pp. 215-237.

29. Birnbaum A. Some latent trait models and their use in inferring an examinee's ability. In: Lord FM, Novick MR, eds. Statistical theories of mental test scores. Reading, MA: Addison-Wesley; 1968. Pp. 396-479.

30. Goldstein H. Multilevel statistical models. 3rd ed. London: Arnold; 2003.

31. Raudenbush SW, Bryk AS. Hierarchical linear models: applications and data analysis methods. 2nd ed. London: Sage Publications; 2002.

32. Leenen I, Givaudan M, Pick S, Venguer T, Vera J, Poortinga Y. Effectiveness of an integral health education program in a poverty stricken rural area of Guatemala. J Cross-Cultural Psychol. In press.
33. Pick S. Extension of theory of reasoned action principles for health promotion programs with marginalized populations in Latin America. In: Ajzen I, Albarracín D, Hornik R, eds. Prediction and change of health behavior: applying a reasoned action approach. Mahwah, NJ.: Lawrence Erlbaum; 2007. Pp. 223-241.

34. Pelto PJ. The differences between "tight" and "loose" societies. Transaction. 1968;5:37-40.

35. Paulhus, DL. Measurement and control of response bias. In: Robinson JP, Shaver PR, Wrightsman LS, eds. Measures of personality and social psychological attitudes. New York: Academic Press; 1991. Pp. 17-59.

36. Gregson S, Zhuwau T, Ndlovu J, Nyamukapa C. Methods to reduce social desirability bias in sex surveys in low-development settings: experience in Zimbabwe. Sex Transm Dis. 2002;29: 568-75.

37. Wagner GP, Miller LG. Adherence in HIV: difficulties in evaluating: is the influence of social desirability on patients self-reported adherence overrated? J Acquir Immune Defic Syndr. 2004;35(2): 203-4.

38. Corneli A, Kleine A, Salvador-Davila G, Gaffikin L, Lewis R, Amankwah A. A qualitative evaluation of the acceptability and feasibility of a single visit approach to cervical cancer prevention in Ghana. Baltimore: JHPIEGO; 2004.

39. Pan American Health Organization. Testing new technologies in the testand-treat project, Peru: The TATI Intervention. Available from: www.paho. org/English/AD/DPC/NC/cctesting newtech.pdf. Accessed 12 October 2004.

40. Riza E, Kyriakogianni-Psaropolou P, Koumantakis E, Symiakaki H, Garas I, Linos A. Cervical cancer screening in Greece. Eur J Cancer. 2002;36:2227-32.

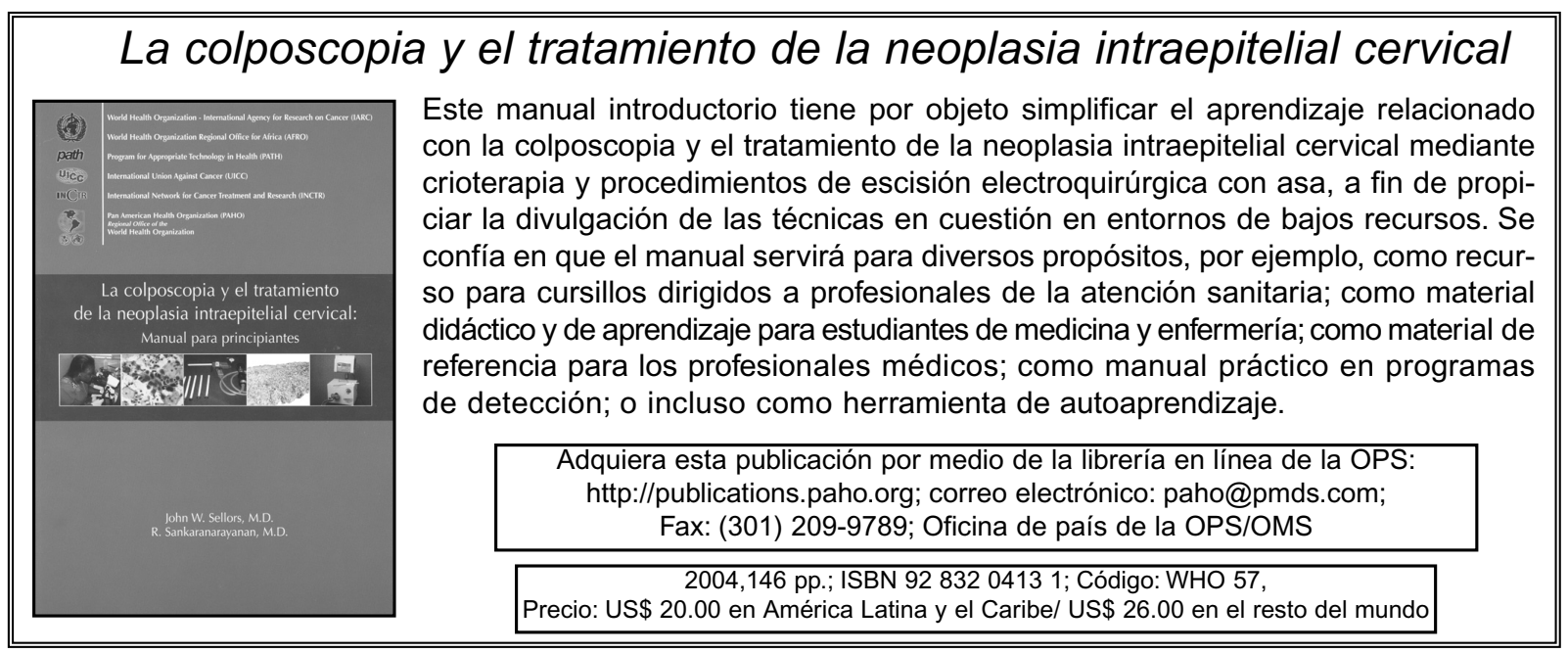

